\title{
Experimental Measurements of Hot Water Stratification in a Heat Storage Tank in Laboratory Conditions
}

\author{
Milan Krafčík ${ }^{1 *}$, Jana Peráčková1 \\ 1 Department of Building Services, Faculty of Civil Engineering, Slovak University of Technology, \\ Radlinského 11, 81005 Bratislava, Slovak Republic \\ * Corresponding author, e-mail: krafcik61@gmail.com
}

Received: 04 February 2019, Accepted: 10 April 2019, Published online: 28 June 2019

\begin{abstract}
The paper focuses on the experimental measurement of the accumulation of hot water storage with its thermal stratificational thermal layers by means created of elementary conical elements. The basic principle of these elements is the automatic distribution of water temperatures according to temperature and volume flow for a specified time of storage of heat energy. This process involves maintaining the thermal stratification at different height levels of the storage tank, which minimizes the process of balancing the hot water. The aim of the experiments was to demonstrate the thermal energy layering in the 1050 I water storage accumulator in 1 hour depending on the different water flow rates from 250 to $1000 \mathrm{l} / \mathrm{h}$ from the heat source.
\end{abstract}

Keywords

hot water, cold water, stratification, temperature, flow

\section{Introduction}

In Slovakia, the domestic hot water preparation is mainly realized in convectional storage water heaters, where the water supply is solved at the bottom of the tank, heated up and the hot water outlet is at the highest point of the water storage. The most up to date, progressive domestic hot water preparation is based on the principle of thermal stratification. It is mainly used to increase the efficiency of solar energy systems and other heat sources by storing hot water in layers in the stratification storage tank $[1,2]$. Water stored in stratified heat storage tanks, forms naturally, as a result of gravity, layers of different temperature affecting its weight [3]. The way water circulates in this kind of heat storage tanks depends on the temperature of heating circuits heated by heat sources. Therefore, there are low temperature systems $\left(30-50^{\circ} \mathrm{C}\right)$ and high-temperature systems $\left(60-90^{\circ} \mathrm{C}\right)$ [4]. Thermal stratification is practically storage volume layering by means of controlled storing of thermal energy into layers with the same or similar temperature. Colder and heavier water remains close to the bottom, whereas warmer water rises upwards. In other words, water with density $\rho$ is always supplied under the layer which has a lower density [5]. The remaining layers maintain their respective temperatures, due to the low thermal conductivity of water. In order to support the preservation of natural thermal layers by means of buoyancy forces, vertical storage tanks are used in most cases $[6,7]$. The control of temperature stratification is usually ensured by means of special self-stratification elements or regulatory elements which are built into storage tanks (see Fig. 1 and 2). Tubular elements are simple elements made from PVC pipes (Fig. 1(a)) [8, 9]. Conical elements allow stratification thanks to their own design, or the so called natural gravity check valve. Branches are made of very light check valves, which prevent temperature changes of the supplied hot water by taking in cooler water from the bottom part of the storage tank (Fig. 1(a) and b, Fig. 2(b)). If we want to achieve a reliable layering of thermal energy, we must not only create differentiated temperature layers, but also maintain them so that the layering of thermal energy in the storage tank will not degrade. The quality of temperature layering of the water stored in the stratified heat storage tank will affect the operating parameters of the whole system. Temperature layering is influenced mainly by the way the working fluid is charged into the storage tank and discharged from it [10].

The above mentioned facts outline the basic difference between a standard storage tank and a stratified storage tank: in a standard storage tank (Fig. 1(c)), a significant 
(a)

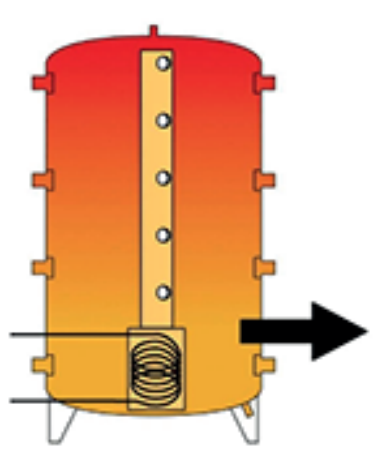

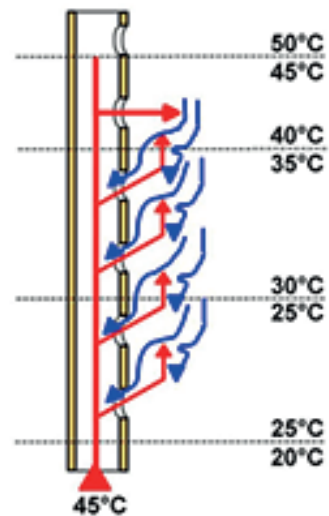

(b)
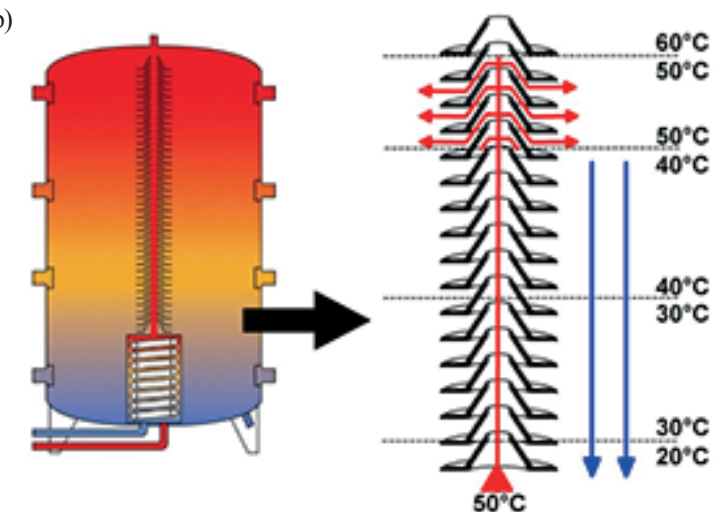

(c)

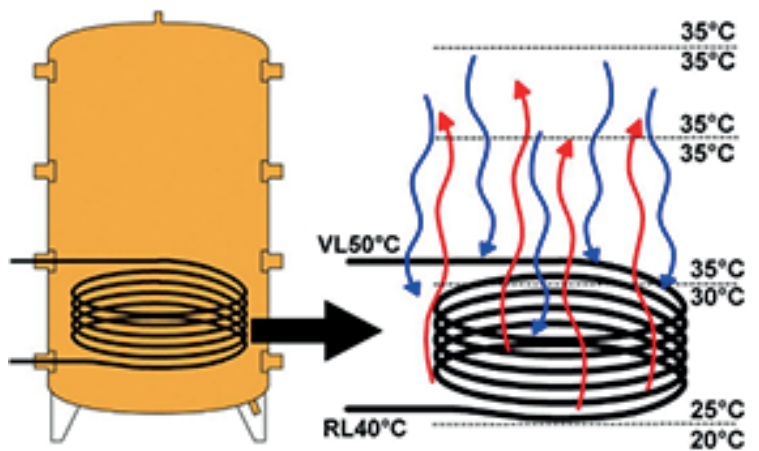

Fig. 1 Ways of layering water in tanks by temperature [11] (a) convective layering of hot water with a plastic tube,

(b) horizontal layering of hot water through cones by rerouting the flow, (c) convective heating of hot water

(a)

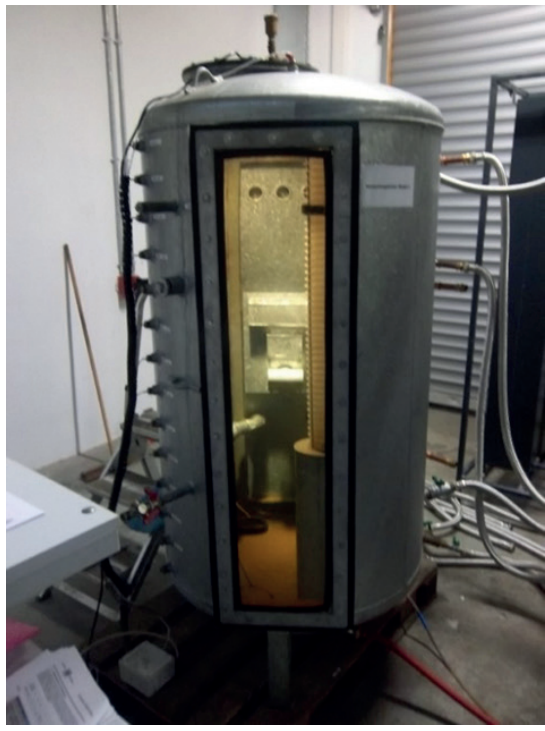

(b)

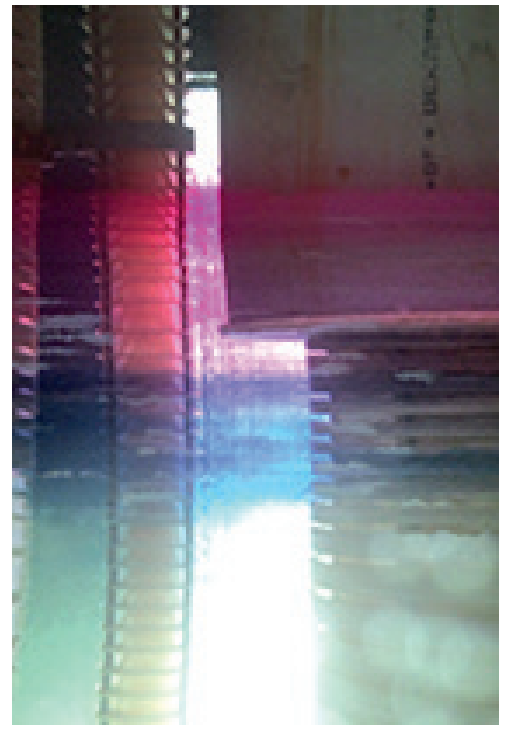

Fig. 2 Stratified storage tank in laboratory conditions [autor] (a) stratified storage tank with a capacity of 1,050 1 in laboratory, (b) color distinction of individual hot water layers in the stratified storage tank

mixing of hot water takes place and the temperature of the water discharged does not meet the requirements of the delivery point, whereas a stratified storage tank (Fig. 1(b)) features internally regulated thermal layering provided by stratifying storage elements (self-acting gravity check valves, plastic conical or plate-like regulatory elements), which allow consumers to discharge hot water from the storage tank with a temperature that fits their needs [12].

2 Experimental measurements in laboratory conditions The experimental measurements were carried out in the testing laboratory of the company SAILER GmbH in Germany 
(Ehingen) (April, May 2017). The measuring module consisted of a thermally no-insulated $1050 \mathrm{~L}$ volume storage tank of steel, with $890 \mathrm{~mm}$ diameter and $1730 \mathrm{~mm}$ height (Fig. 2) in which there was no hot water extraction during the experiment. It is equipped with an expansion vessel with a capacity of 501 with an automatic vent valve and a drain valve with a location at the top of the tank.

Elemental conical elements of plastic for the primary circuit from the heat source and the circuit from the solar system are located in the storage tank. They are connected to with the heat exchanger, which inside the container for the solar system. Conical elements are used for steady temperature layering. Changes in heat energy layering of the thermal energy storage in the storage tank is recorded by the sensors in individual height levels divided by stages at a distance of $10 \mathrm{~cm}$, marked T1 to T13 (Table 1) on the left edge of the storage tank. Temperature sensors on the supply and return heating pipes are too located in the individual points of the measuring heating system. The measuring and control system is installed on the primary heating circuit from the heat sources upstream of the storage tank, followed by a heat exchanger. The constant flow rate is controlled by the setting unit of pumps assembly for the experiment. The heating water is supplied to the measuring device through a copper pipe with a nominal lightness/diameter DN 20 (22 x $1.0 \mathrm{~mm})$. There were two heat sources used for water heating: the first one consisted of 10 solar collectors with an absorption area of $10 \times 2.81 \mathrm{~m}^{2}$, the second one was a gas condensing boiler with a heat output of $30 \mathrm{~kW}$.

At the beginning of the measurement, the storage tank is fully filled by water with the temperature of 35 to $36^{\circ} \mathrm{C}$. The hot water is supplied from the heat source through the heat exchanger so that it is mixed to the desired temperature (Fig. 3). The water is supplied to the top layer of the storage tank at point " $C$ ". The temperature of the top layer keeps increasing until the water temperature at point $\mathrm{T} 11$ is higher than $50{ }^{\circ} \mathrm{C}$. The experimental set is prepared for the measurements when the water in the storage tank is divided into 13 thermal layers ranging from 35 up to about $59{ }^{\circ} \mathrm{C}$ in the top. This procedure is repeated before each measurement so that the initial conditions are always the same throughout the whole tank. During the experiment, the water temperatures are recorded every second over the whole height of the tank in all the 13 thermal layers. The volume flow rates at point A (Fig. 3) were $250 \mathrm{l} / \mathrm{h}$ (4.16 l/min), $500 \mathrm{l} / \mathrm{h}(8.3 \mathrm{l} / \mathrm{min}), 750 \mathrm{l} / \mathrm{h}$ (12.5 1/min), and $1000 \mathrm{l} / \mathrm{h}(16.3 \mathrm{l} / \mathrm{min})$. The storage tank is connected to a heat source (natural gas boiler) with the temperature gradient of $45 / 35^{\circ} \mathrm{C}$ (Fig. 3, point 5). The aim was to observe the process of creation of the thermal layers with $45^{\circ} \mathrm{C}$ temperature over time.

\section{Results}

During one-hour interval, the stratification of thermal energy layering at different height levels had been determined in the storage tank. Different flow rates were used - 250 1/h, 500 1/h (Fig. 4), 750 1/h (Fig. 5) and 1,000 1/h (Fig. 6) - in order to determine the difference between the stratification behavior and efficiency of thermal energy storage. The measuring device recorded the temperature values in the interval of every second. The measured values of water temperature course are shown on the figures, in 13 measured layers in 1 hour interval. Table 1 shows an example of hot water temperatures measured in the storage by flow rate of 1,000 1/h over an interval of 5 minutes.

The thermally layered water has a volume flow rate of $500 \mathrm{l} / \mathrm{h}$ (Fig. 4) with the temperatures of $35.6{ }^{\circ} \mathrm{C}, 36^{\circ} \mathrm{C}$, $38.6{ }^{\circ} \mathrm{C}, 55.9{ }^{\circ} \mathrm{C}$, and $59.2{ }^{\circ} \mathrm{C}$. The temperature at the top layer $\mathrm{T} 13$ decreases from $59.2{ }^{\circ} \mathrm{C}$ down to $55.9{ }^{\circ} \mathrm{C}$ (3.3 K). The sensors T11 and T12 with temperatures of $55.8^{\circ} \mathrm{C}$ and $59{ }^{\circ} \mathrm{C}$, respectively, indicate decrease in the water temperature at the volume flow rates of $750 \mathrm{l} / \mathrm{h}$ and $1000 \mathrm{l} / \mathrm{h}$. The thermal layer T10 with the initial temperature of $38.5{ }^{\circ} \mathrm{C}$ has reaches $47.8{ }^{\circ} \mathrm{C} 13$ minutes after the measurement had started. This temperature of the thermal

Table 1 Example of water temperature changes in the tank at the flow of $1,000 \mathrm{l} / \mathrm{h}$

\begin{tabular}{|c|c|c|c|c|c|c|c|c|c|c|c|c|c|}
\hline \multirow{2}{*}{ Time (min) } & \multicolumn{13}{|c|}{ Sensor temperature in individual layers in ${ }^{\circ} \mathrm{C}$} \\
\hline & $\mathrm{T}_{-} 1$ & T_2 & $\mathrm{T}_{-} 3$ & $\mathrm{~T}_{-} 4$ & T_5 & T_6 & $\mathrm{T}_{-} 7$ & $\mathrm{~T}_{-} 8$ & T_9 & $\mathrm{T}_{-} 10$ & $\mathrm{~T}_{-} 11$ & T_12 & $\mathrm{T}_{-} 13$ \\
\hline 0 & 35.10 & 35.30 & 35.46 & 35.49 & 35.60 & 35.60 & 35.60 & 35.80 & 39.65 & 50.2 & 55.2 & 56.9 & 56.5 \\
\hline 1 & 35.11 & 35.30 & 35.48 & 35.49 & 35.60 & 35.60 & 35.60 & 35.90 & 41.03 & 50.4 & 54.8 & 57 & 56.3 \\
\hline 2 & 35.11 & 35.30 & 35.48 & 35.49 & 35.60 & 35.60 & 35.60 & 36.25 & 41.92 & 50.6 & 54.6 & 56.8 & 56.3 \\
\hline 3 & 35.10 & 35.30 & 35.47 & 35.49 & 35.60 & 35.60 & 35.61 & 36.65 & 42.68 & 50.4 & 54.4 & 56.8 & 56.2 \\
\hline 4 & 35.10 & 35.30 & 35.49 & 35.50 & 35.59 & 35.60 & 35.60 & 37.26 & 43.40 & 50.3 & 54.3 & 56.8 & 56.2 \\
\hline 5 & 35.10 & 35.30 & 35.48 & 35.50 & 35.60 & 35.60 & 35.60 & 37.99 & 43.99 & 50.2 & 54 & 56.8 & 56.1 \\
\hline
\end{tabular}




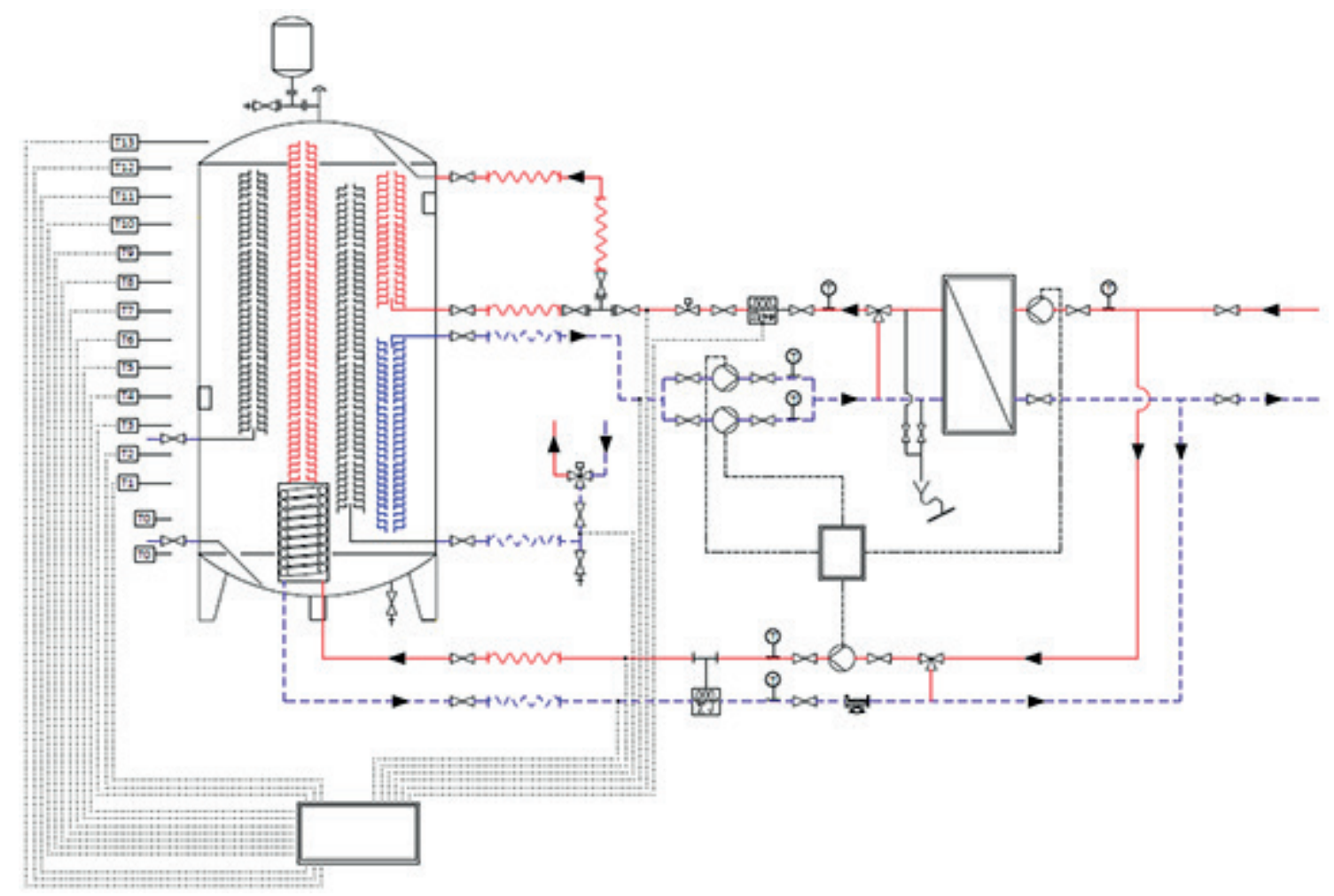

Fig. 3 Hydraulic scheme of the connection of stratified storage tank during the experimental measurements [autor]. 1 - stratified storage tank (1,050 1), 2 - control unit with a data saving feature, 3 - plate heat exchanger, 4 - pump control unit, 5 - heating system from solar collectors or gas boiler, A primary supply from heat source, $\mathrm{B}$ - primary supply from solar system, $\mathrm{C}$ - water inlet for temperature layers above $50^{\circ} \mathrm{C}$

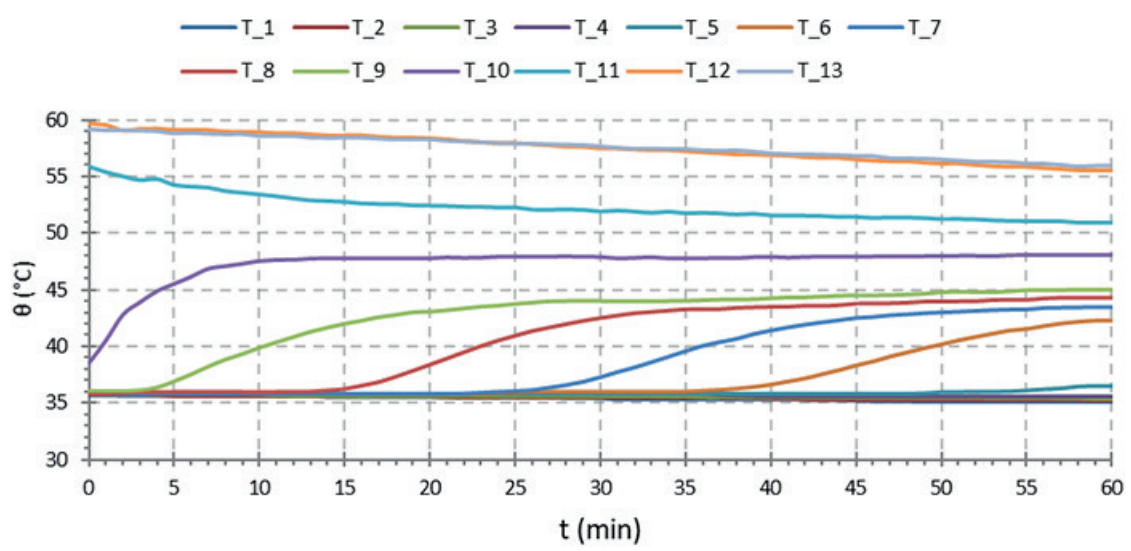

Fig. 4 Changes in heat energy layering by temperature at the flow of $500 \mathrm{l} / \mathrm{h}$

layer is kept until the end of the measurement. The initial temperatures at the sensors $\mathrm{T} 9, \mathrm{~T} 8, \mathrm{~T} 7$ and $\mathrm{T} 6$ are about $36{ }^{\circ} \mathrm{C}$. The temperature at T9, T8, T7 and T6 rises above $40{ }^{\circ} \mathrm{C} 11,23,36$ and 50 minutes after the measurement had started, respectively. The thermal layer keeps the temperature of $35.8^{\circ} \mathrm{C}$ during the first 55 minutes, whereupon it rises slightly to $36.5^{\circ} \mathrm{C}$. T4 is kept at 35.8 to $36{ }^{\circ} \mathrm{C}$, and $\mathrm{T} 1$ to $\mathrm{T} 3$ are at $35.5^{\circ} \mathrm{C}$ over the whole $60 \mathrm{~min}$ utes. For the volume flow rate of $750 \mathrm{l} / \mathrm{h}$ the temperatures of the thermal layers at the beginning of the measurement are $36.6{ }^{\circ} \mathrm{C}, 39{ }^{\circ} \mathrm{C}, 43.2^{\circ} \mathrm{C}, 54.1^{\circ} \mathrm{C}$, and $56.1^{\circ} \mathrm{C}$ (Fig. 5). Temperature of the top layer $\mathrm{T} 13$ decreases from 56.1 to $52.02{ }^{\circ} \mathrm{C}(4.08 \mathrm{~K})$. Also the sensors $\mathrm{T} 11$ and $\mathrm{T} 12$ with the temperatures of $54.1^{\circ} \mathrm{C}$ and $56.1^{\circ} \mathrm{C}$, respectively, indicate cooling down of the water. After 25 minutes the temperatures at these layers are below $50{ }^{\circ} \mathrm{C}$. The temperatures at $\mathrm{T} 10$ to $\mathrm{T} 6$ are after 20 minutes approaching $48{ }^{\circ} \mathrm{C}$. After 35 minutes they are approximately constant between 47 and $48{ }^{\circ} \mathrm{C}$. The temperature of the thermal layer $\mathrm{T} 5$ increases between the $14^{\text {th }}$ minute and the 


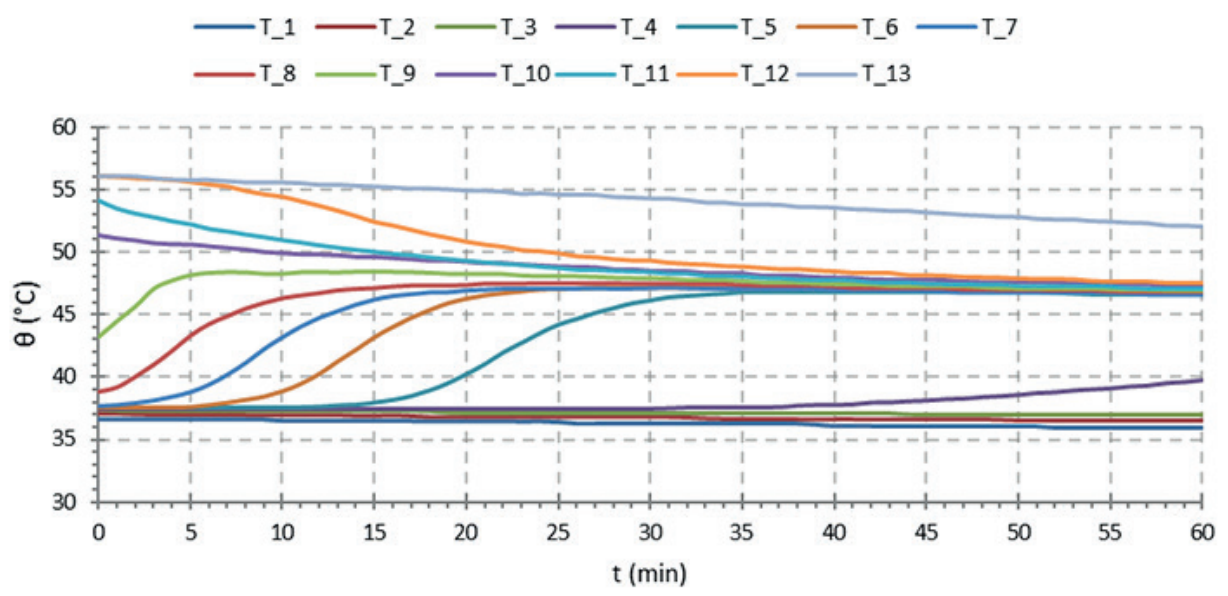

Fig. 5 Changes in heat energy layering by temperature at the flow of $750 \mathrm{l} / \mathrm{h}$

$35^{\text {th }}$ minute from $37.8^{\circ} \mathrm{C}$ up to $47.3^{\circ} \mathrm{C}$. The temperature in $\mathrm{T} 4$ rises from $37.4{ }^{\circ} \mathrm{C}$ in the $25^{\text {th }}$ minute up to the $39.75^{\circ} \mathrm{C}$.

The thermal layer T3 keeps its temperature at $36.9^{\circ} \mathrm{C}$ over the whole measurement. The lowest thermal layers $\mathrm{T} 2$ and $\mathrm{T} 1$ have temperatures of about $37^{\circ} \mathrm{C}$ and $36^{\circ} \mathrm{C}$, respectively. For the volume flow rate of $1000 \mathrm{l} / \mathrm{h}$ the temperatures of the thermal layers over the whole measurement are Fig. 6. The water in the storage tank did not drop below the initial value of $35^{\circ} \mathrm{C}$ over the whole measurement. Its maximum value was about $59^{\circ} \mathrm{C}$ (Fig. 6), while the goal was to heat up the whole volume of the tank to the average of $45^{\circ} \mathrm{C}$. Fig. 7 shows the course of supply water temperature from the heat source with a temperature gradient of $45 / 35^{\circ} \mathrm{C}$ at the volume flow rates of $500 \mathrm{l} / \mathrm{h}(8.3 \mathrm{l} / \mathrm{min})$ and $750 \mathrm{l} / \mathrm{h}(12.5 \mathrm{l} / \mathrm{min})$. At the volume flow rate of $500 \mathrm{l} / \mathrm{h}$, the thermal gradient is gradually dropping over the one-hour measurement from the 10 $\mathrm{K}\left(45 / 35^{\circ} \mathrm{C}\right)$ down to $6.5 \mathrm{~K}$. A flow $750 \mathrm{l} / \mathrm{h}$ with temperature gradient of $45 / 35^{\circ} \mathrm{C}$ gradually decreases from $9.8 \mathrm{~K}$ to 2.4 $\mathrm{K}$. The example of the hot water temperature course at the height levels from 0 to $1700 \mathrm{~mm}$ is documented in Fig. 8. It expresses changes in temperature at the height levels of stratified storage tank at flow rate $750 \mathrm{l} / \mathrm{h}$ at the beginning of the measurement, after 30 minutes and 1 hour.

\section{Discussion}

The aim of the experiment was to demonstrate the dependence of the thermal energy layering with flow rates from 250 to $1000 \mathrm{l} / \mathrm{h}$. The determined volumetric flow rate had been provided to the storage tank, while the temperature had been measured in different heights $-400 \mathrm{~mm}$; $1200 \mathrm{~mm} ; 1700 \mathrm{~mm}$. The input data is shown in Table 2. During the measurements $35-36{ }^{\circ} \mathrm{C}$ had been measured in the lower part of the tank. At the center temperatures reached $45-47^{\circ} \mathrm{C}$ and in the upper part at $1.7 \mathrm{~m}$ height 53-55 ${ }^{\circ} \mathrm{C}$ had been measured. Fig. 4, 5 and 6 shows that the optimal heat energy layering flow rate was $750 \mathrm{l} / \mathrm{h}$. For the flow rates of $250 \mathrm{l} / \mathrm{h}$ and $500 \mathrm{l} / \mathrm{h}$ the water is heated only in the lower thermal layers (sensors T6 to T9) up to

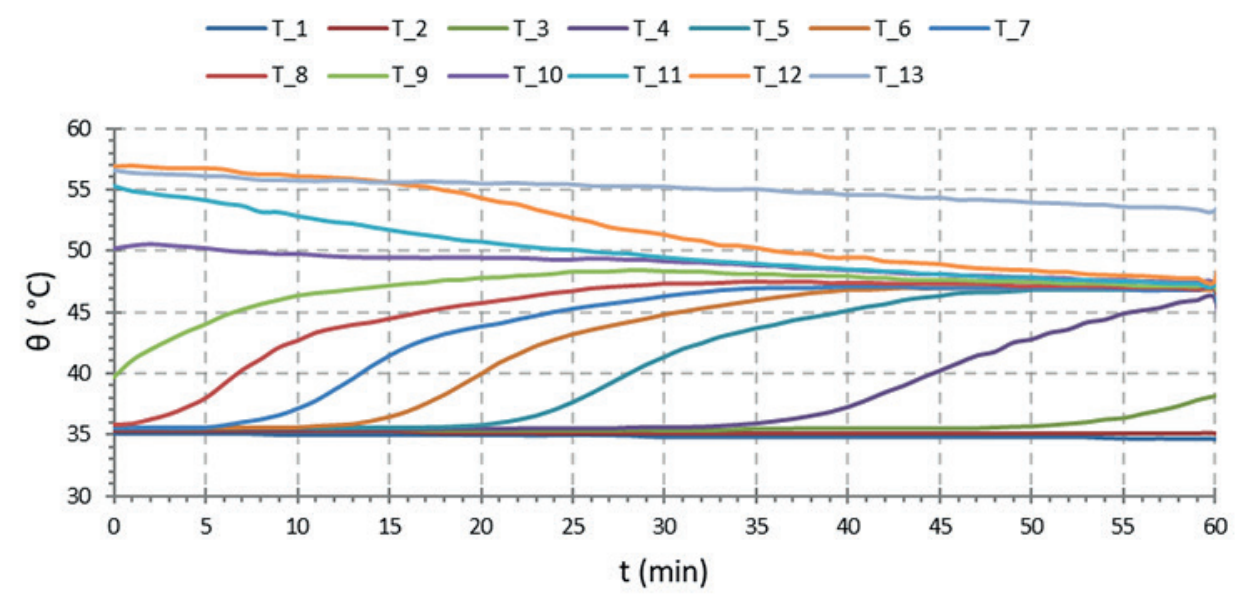

Fig. 6 Changes in heat energy layering by temperature at the flow of 1,000 1/h 
Table 2 Water temperature in different height levels of the storage tank with changing flow rate

\begin{tabular}{lccccccccccccc}
\hline Flow $(1 / \mathrm{h})$ & & 250 & \multicolumn{3}{c}{500} & & & 750 & & & & \\
$\quad$ Indicatiion & $\mathrm{T} 1$ & $\mathrm{~T} 10$ & $\mathrm{~T} 13$ & T1 & T10 & T13 & T1 & T10 & T13 & T1 & T10 & T13 \\
Sensor height (m) & 0.4 & 1.2 & 1.7 & 0.4 & 1.2 & 1.7 & 0.4 & 1.2 & 1.7 & 0.4 & 1.2 & 1.7 \\
Temperature $\left({ }^{\circ} \mathbf{C}\right)$ & 34.8 & 45 & 54.6 & 35.1 & 44.9 & 55.9 & 35.9 & 46.9 & 52.1 & 34.6 & 46.9 & 53.4 \\
\hline
\end{tabular}
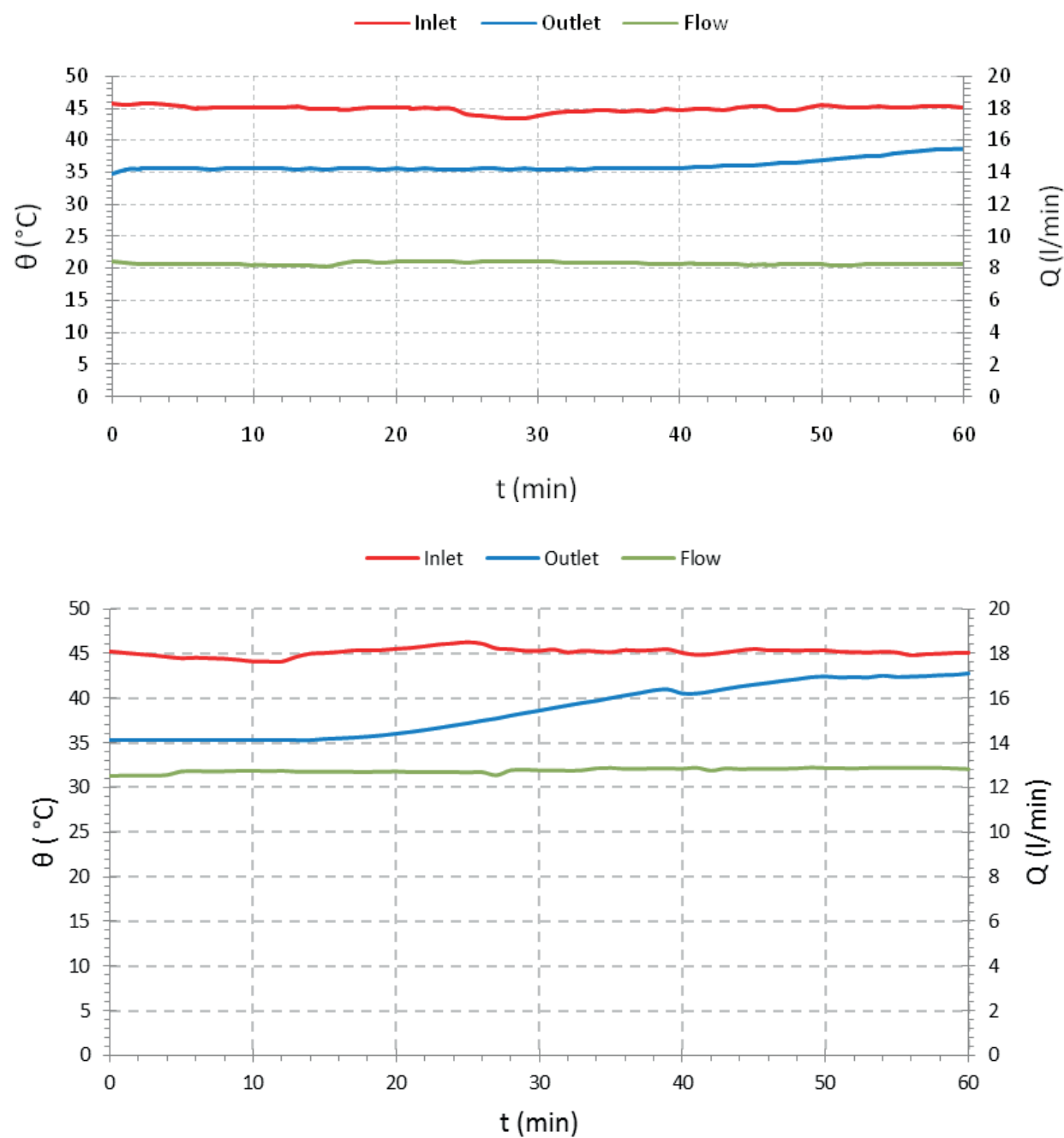

Fig. 7 Water supply with temperature gradient of $45 / 35^{\circ} \mathrm{C}$ from heat source at flow rates of 500 and $750 \mathrm{l} / \mathrm{h}$

the height of $1.2 \mathrm{~m}$. These thermal layers are heated up to $43{ }^{\circ} \mathrm{C}$ to $45^{\circ} \mathrm{C}$. For the flow rate of $750 \mathrm{l} / \mathrm{h}$ the thermal layers located between $0.6 \mathrm{~m}$ and $1.5 \mathrm{~m}$ are after 35 minutes heated up to the temperature of $47{ }^{\circ} \mathrm{C}$ to $49{ }^{\circ} \mathrm{C}$. For the flow rate of $1000 \mathrm{l} / \mathrm{h}$ the thermal layers located between $0.6 \mathrm{~m}$ and $1.4 \mathrm{~m}$ are after 40 minutes heated up to the temperature of $47^{\circ} \mathrm{C}$ to $49{ }^{\circ} \mathrm{C}$.

The larger the volume flow to the storage from the heat source, the temperature of the hot water at the highest temperature layers decreased from $55^{\circ} \mathrm{C}$ to $47^{\circ} \mathrm{C}$ and the lower temperature increased from $35^{\circ} \mathrm{C}$ to over $45^{\circ} \mathrm{C}$. The volumetric flow rate has a great influence cooling down the water in the higher layers therefore it is necessary to design the inlet volume flow rate to the heating and hot water preparation system.

\section{Conclusion}

The advantage of stratification storage tanks is the usage of hot water according to the temperature of the selected heating system and distribution system. Temperatures around $30-50{ }^{\circ} \mathrm{C}$ stored in the lower part of the stratified tank can be used from the low exergy system. Water from the middle and upper part of the tank with $60-90{ }^{\circ} \mathrm{C}$ can be used for hot water heating and domestic hot water 


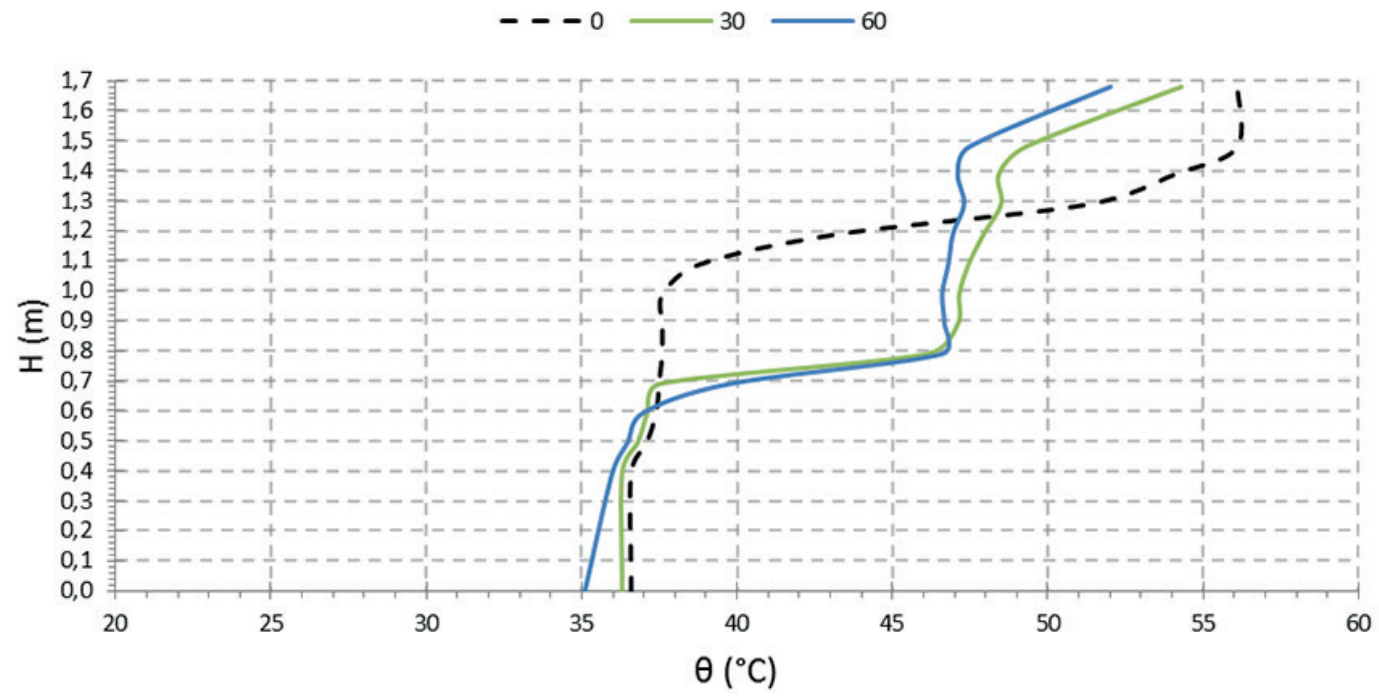

Fig. 8 Changes in temperature at the height levels of stratified storage tank at flow rate $750 \mathrm{l} / \mathrm{h}$

preparation. It is very important to properly set and install the inlet and outlet water flow to the system of heat accumulation. If they do so the heat storage accumulator tanks are highly efficient combined to the heating and DHW systems, minimizing heating time compared to other hot water storage tanks with convective heating.

\section{References}

[1] Rhee, J., Campbell, A., Mariadass, A., Morhous, B. "Temperature stratification from thermal diodes in solar hot water storage tank", Solar Energy, 84(3), pp. 507-511, 2010.

https://doi.org/10.1016/j.solener.2009.12.007

[2] Taheri, H., Schmidt, F. P., Gabi, M. "Numerical Investigation of Effective Heat Conductivity of Fluid in Charging Process of Thermal Storage Tank", Open Journal of Fluid Dynamics, 5(1), pp. 39-50, 2015.

https://doi.org/10.4236/ojfd.2015.51006

[3] Han, Y. M., Wang, R. Z., Dai, Y. J. "Thermal stratification within the water tank", Renewable and Sustainable Energy Reviews, 13(5), pp. 1014-1026, 2009.

https://doi.org/10.1016/j.rser.2008.03.001

[4] Garbai, L., Jasper, A., Magyar, Z. "Probability theory description of domestic hot water and heating demands", Energy and Buildings, 75, pp. 483-492, 2014.

https://doi.org/10.1016/j.enbuild.2014.01.050

[5] Matuška, T. "Zásobníky tepla s řízeným teplotním vrstvením (stratifikací)", 2010. (in Slovak) [online] Available at: https://oze.tzbinfo.cz/solarni-kolektory/156-zasobniky-tepla-s-rizenym-teplotnim-vrstvenim-stratifikaci [Accessed: 03 February 2019]

[6] Smusz, R., Kielan, P., Mazur, D. "Analysis of thermal stratified storage tank", Archives of Electrical Engineering, 66(3), pp. 631642, 2017.

https://doi.org/10.1515/aee-2017-0048

\section{Acknowledgment}

This work was supported by the Slovak Research and Development Agency under the contract No. DS-2016300 and by the Ministry of Education, Science, Research and Sport of the Slovak Republic under VEGA Grant 1/0807/17 and VEGA Grant 1/0847/18.

[7] Zachár, A. "Investigation of a new tube-in-tube helical flow distributor design to improve temperature stratification inside hot water storage tanks operated with coiled-tube heat exchangers", International Journal of Heat and Mass Transfer, 63, pp. 150-161, 2013. https://doi.org/10.1016/j.ijheatmasstransfer.2013.03.055

[8] Bracamonte, J., Parada, J., Dimas, J., Baritto, M. "Effect of the collector tilt angle on thermal efficiency and stratification of passive water in glas evacuated tube solar water heater", Applied Energy, 155, pp. 648-659, 2015.

https://doi.org/10.1016/j.apenergy.2015.06.008

[9] Gasque, M., González-Altozano, P., Maurer, D., MonchoEsteve, I. J., Gutiérrez-Colomer, R. P., Palau-Salvador, G., GarcíaMarí, E. "Study of the influence of inner lining material on thermal stratification in a hot water storage tank", Applied Thermal Engineering, 75, pp. 344-356, 2015.

https://doi.org/10.1016/j.applthermaleng.2014.10.040

[10] Krafčík, M., Peráčková, J. "Stratifikácia teplej vody vo vrstvovom akumulačnom zásobníku" (Stratification of Hot Water in the Storage Tank), TZB-Haustechnik, 26(5), pp. 34-36, 2017.

[11] Firma Sailer "Sailer Einschichtvorrichtung", 2017. (in German)

[12] Krafčík, M., Peráčková, J. "The Stratified Heat Storage Tanks", Magyar Épületgépészet, 66(6), pp. 30-33, 2017. 